
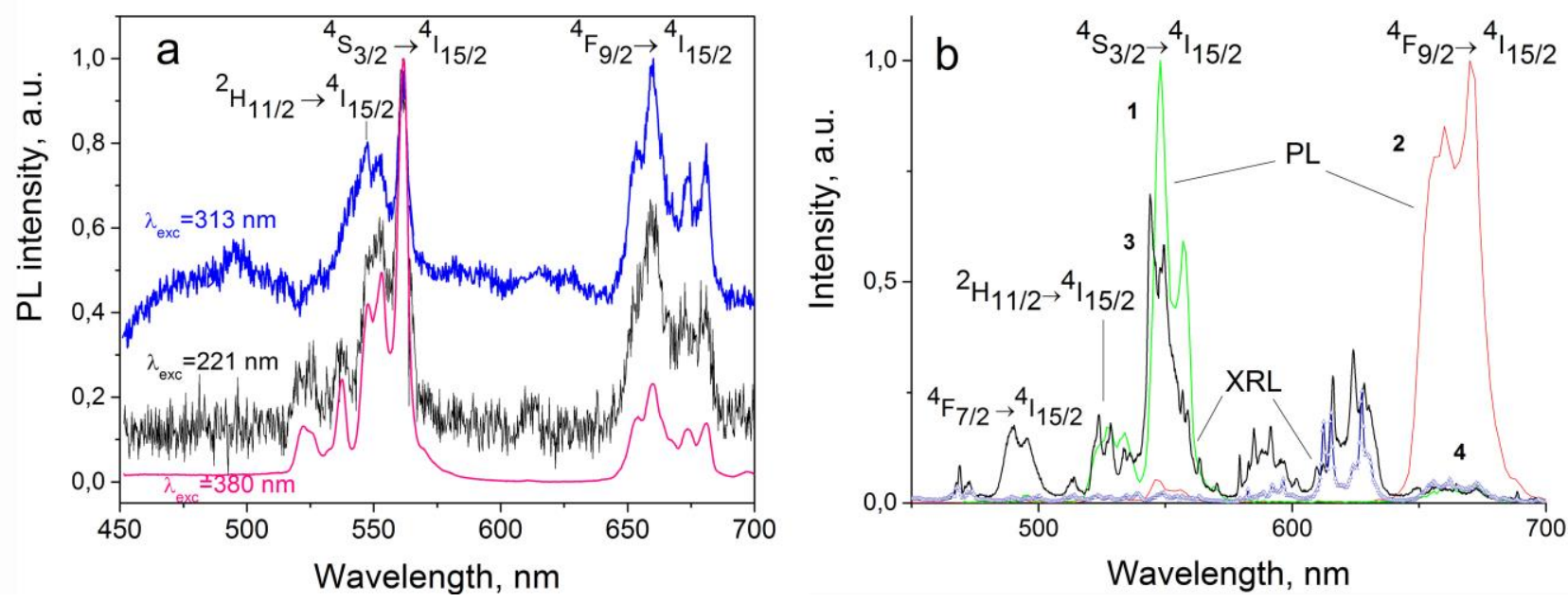

Fig. 1. a - PL spectra of $\mathrm{Gd}_{2} \mathrm{O}_{3}$ :Er under different $\lambda_{\text {exc }} ; b-\mathrm{PL}\left(\lambda_{\text {exc }}=980 \mathrm{~nm}\right)$ and XRL spectra of $\mathrm{Gd}_{2} \mathrm{O}_{3}: \operatorname{Er}(1,2)$ and $\mathrm{Gd}_{2} \mathrm{O}_{3}: \operatorname{Er}+\mathrm{Zn}(3,4)$

1. Zatsepin A., Kuznetsova Yu., Spallino L., Pustovarov V., Rychkov V., Energy Procedia, 102, 144 (2016).

2. Kuznetsova Yu.A., Zatsepin A.F., Tselybeev R.A., Rychkov V.N., and Pustovarov V.A., Journal of Physics: Conf. Series, 741, 012089 (2016).

\title{
DOWNHOLE TELEMETRY SYSTEM RELIABILITY CALCULATION AND IMPROVEMENT
}

\author{
Trofimova E.S. ${ }^{1 *}$, Rubtsova O.O. ${ }^{1}$, Ishchenko A.V. ${ }^{1}$, Danilov V.Yu. ${ }^{2}$ \\ ${ }^{1)}$ Ural Federal University, Yekaterinburg, Russia
}

${ }^{2)}$ Scientific and Production Association of automatics, Yekaterinburg, Russia

*E-mail: trofimova.e.s@yandex.ru

Downhole telemetry systems are widely used in oil mining industry for oil extraction control and monitoring. These systems consist of ground-based and subterranean units, connected by communication line. The main unit - subterranean - contains temperature and pressure sensors, analog-to-digital convertors, microcontrollers etc. Being used deeply underground, downhole system is exposed to high temperatures (up to $200{ }^{\circ} \mathrm{C}$ ), high pressure, vibration and other factors of harsh environment. Tests show that maximum non-failure operation time for downhole systems made in Russia does not exceed 200 days, and mean time to failure is approximately 100 days [1].

Present work reviews the methods of reliability improvement for the given downhole telemetry system in severe operating conditions. Calculations were made for the device under development at Ural Federal University.

At the first stage mean time to failure at temperature $150{ }^{\circ} \mathrm{C}$ was estimated to be approximately 250 days. The transistor module of the downhole unit was found to be 
the least reliable. This unit is a part of the power supply circuit and cannot be replaced or reviewed. Therefore the only measure for this module is redundancy.

Several measures were taken to prolong device lifetime. Certain electronic components were replaced with high temperature analogs. Various types of redundancy were used for least reliable components and units. Combination of these measures made it possible to increase mean time to failure up to 420 days.

Work on PNIER RFMEFI57815X0134 performed with the financial support of the Ministry of Education and Science of the Russian Federation in the framework of the agreement №14.578.21.0134 on 27 October 2015.

1. Степанов С.Г., Термостойкая погружная телеметрия, Нефтегазовая вертикаль, 21, $50(2011)$.

\title{
INVESTIGATION OF INTERFERENCE TO RADIO NETWORKS OF THE STANDARD IEEE 802.11
}

\author{
Matysin A.N. ${ }^{1 *}$, Lagunov A.J. ${ }^{1}$, Terekhin V.D. ${ }^{1}$ \\ ${ }^{1)}$ Northern (Arctic) Federal University named after M.V. Lomonosov, \\ Arkhangelsk, Russia \\ *E-mail: thececlioco@gmail.com
}

Now wireless computer networks have received a wide circulation. The equipment of such networks, according to IEEE, are worked in a range of $2,4 \mathrm{GHz}$ or $5 \mathrm{GHz}$ and is capable to transfer the data with the maximal speed $300 \mathrm{Mbit} / \mathrm{s}$ [1]. Real speed of data transmission strongly depends on a level of handicapes to which problem of reduction the this research is devoted.:

- the problems of electromagnetic compatibility existing in WLAN;

- problem of the latent unit;

- mutual handicapes between next cells (intersystem electromagnetic compatibility);

- intersystem electromagnetic compatibility;

- supplying QoS for critical appendices;

- influence of features of district.

Problems of electromagnetic compatibility (intrasystem and intersystem) are solved at designing the equipment of a wireless network (the various ways of coding raising a noise stability) and at designing of directly most wireless network are for example used. At that the opportunities incorporated in means, define facilities of the designer of a network.

Mechanisms of the control bearing with the help of time division provide simultaneous work only one transmitter in one cell. At presence of handicapes this mechanism 